\title{
PELATIHAN ONLINE MENULIS PENELITIAN LITERATUR DI MASA PANDEMI COVID-19 BAGI GURU INOVATIF
}

\author{
ZINNURAIN, MUHAMAD SUHARDI \\ Fakultas Ilmu Pendidikan dan Psikologi Universitas Pendidikan Mandalika \\ email: zinnurain@undikma.ac.id
}

\begin{abstract}
ABSTRAK
Kondisi pandemic Covid-19 yang sudah memasuki fase tahun ke-3 masih menjadi kendala utama bagi guru dalam mengikuti kegiatan pengembangan diri secara fisik (luar jaringan) di setiap kegiatan. Hal ini menuntut guru mampu beradaptasi dalam mengikuti setiap kegiatan yang diperlukan dalam pengembangan dirinya, salah satu kegiatan tersebut yaitu pelatihan menulis penelitian literature. Adapun kegiatan pelatihan dilaksanakan dalam upaya mengembangkan keterampilan guru dalam menulis penelitian literature dalam upaya peningkatan dan pengembangan diri dalam karir guru sebagai bagian dari pengembangan keprofesian berkelanjutan. Berdasarkan hasil pra-survey yang dilakukan oleh tim di awal tahun 2021, didapatkan fakta kondisi para guru di NTB masih kesulitan dalam mengikuti kegiatan pelatihan secara langsung dikarenakan pandemic Covid-19. Hal ini berpengaruh pasti terhadap pengembangan diri guru salah satunya yaitu keterampilan menulis penelitian. Oleh karena itu, kegiatan pengabdian kepada masyarakat ini dilakukan secara online sebagai upaya mengatasi kendala kehadiran guru dengan tujuan memberikan kesempatan bagi guru dalam meningkatkan keterampilan menulis penelitian literature. Adapun metode yang digunakan dalam kegiatan ini adalah berupa pelatihan online menulis penelitian literatur yang dilaksanakan selama 3 hari yaitu pada 22-24 November 2021. 1) Para guru sebagian besar sudah mampu mengembangkan kompetensi diri yakni para guru memahami secara teoritis mengenai penelitian literatur. 2) Para guru sebagian besar sudah terampil dalam menyusun serta mengembangkan penelitian literature sebagai bagian dari pengembangan profesi berkelanjutan yang dibutuhkan oleh para guru dalam meningkatkan mutu pendidikan di NTB.
\end{abstract}

Kata Kunci: pelatihan online, penelitian literature, pandemic covid-19.

\section{ABSTRACT}

The condition of the Covid-19 pandemic, which has entered the 3rd year phase, is still the main obstacle for teachers in participating in physical development activities (outside the network) in every activity. This requires teachers to be able to adapt in participating in every activity needed in their self-development, one of these activities is literature research writing training. The training activities are carried out in an effort to develop teacher skills in writing literature research in an effort to improve and develop themselves in a teacher's career as part of continuous professional development. Based on the results of a pre-survey conducted by the team in early 2021, it was found that the condition of teachers in NTB was still having difficulty participating in direct training activities due to the Covid-19 pandemic. This has a definite effect on the teacher's self-development, one of which is research writing skills. Therefore, this community service activity is carried out online as an effort to overcome the obstacles in the presence of teachers with the aim of providing opportunities for teachers to improve their writing skills in literature research. The method used in this activity is in the form of online training in writing literature research which is carried out for 3 days, namely on November 2224 2021. 1) Most of the teachers have been able to develop self-competence, namely teachers understand theoretically about literature research. 2) Most of the teachers are skilled in compiling and developing literature research as part of the continuous professional development needed by teachers in improving the quality of education in NTB.

Keywords: online training, literature research, the covid-19 pandemic. 


\section{PENDAHULUAN}

Merebaknya wabah Corona Virus Desease 19 (Covid-19) sampai dengan saat ini sangat mempengaruhi kebiasaan ummat manusia yang ada di seluruh penjuru dunia (Lim, et al: 2020). Segala bentuk kegiatan kehidupan manusia yang awalnya berjalan normal saat ini harus disesuaikan dengan kondisi tiap negara. Pembatasan pergerakan manusia secara global sangat mempengaruhi kegiatan dan aktifitas manusia (Karim, et al: 2020). Begitu juga kondisi pembatasan kegiatan tersebut tidak terlepas dialami di negara Indonesia. Seperti yang diketahui Indonesia sendiri telah memasuki fase tahun ke-3 dalam menghadapi penyebaran covid-19. Berbagai upaya telah dilakukan dalam menekan penyebaran virus tersebut. Mulai dari membatasi mobilitas warga negara untuk bepergian baik dari dalam dan ke luar negeri, ataupun bepergian dari satu daerah ke daerah yang lain di dalam negeri. Begitu juga kegiatan yang lain seperti kegiatan ekonomi bahkan sampai kegiatan dalam pendidikanpun tidak terlepas dari pembatasan tersebut.

Adapun pembatasan yang dilakukan di bidang pendidikan menjadikan pemerintah pusat dan daerah, terutama di Nusa Tenggara Barat (NTB) terjadi adanya penyesuaian dan pembatasan. Sekolah-sekolah yang ada di NTB diharuskan mengikuti peraturan pemerintah dalam hal memobilisasi warga sekolahnya secara terbatas bahkan diliburkan untuk datang ke sekolah secara total. Kegiatan pembelajaran harus dilaksanakan secara dalam jaringan (online) sebagai upaya membatasi kontak langsung baik para guru dan siswa saat mengikuti pembelajaran (Handarini, et al: 2020).

Pembatasan kehadiran sangat berpengaruh signifikan terhadap keefektifan kegiatan di sekolah. Hal ini menjadi pengalaman baru sekaligus menjadi kekhawatiran bagi warga sekolah terhadap kegiatan baik proses pembelajaran maupun kegiatan ekstra lainnya yang diikuti oleh guru dan siswa (Sadikin, et al: 2020, Sihotang, et al: 2020). Begitu juga hal tersebut terjadi bagi sekolah-sekolah yang ada di NTB, termasuk yang dialami oleh para guru dalam kegiatan pengembangan diri di bidangnya.

Guru sebagai tenaga pendidik profesional adalah guru yang tidak hanya merasa puas dengan pengetahuan dan keterampilan yang sudah dimiliki. Seorang guru sebagai tenaga profesional hendaklah berusaha mengembangkan pengetahuan dan keterampilannya sehingga layanan yang diberikan kepada peserta didik adalah layanan yang semakin berkualitas. Tugas seorang guru profesional tidak hanya dituntut untuk memiliki kinerja yang baik dalam melaksanakan tugas mengajar, mendidik dan melatih peserta didik saja melainkan juga harus melakukan pengembangan keprofesian berkelanjutan. Berbagai hal bisa dilakukan oleh seorang guru untuk dapat meningkatkan profesionalismenya (Windrawanto: 2015).

Berdasarkan hasil observasi yang dilakukan di awal tahun 2021 kepada para guru yang tersebar di seluruh wilayah provinsi nusa tenggara barat (NTB), didapatkan fakta bahwa sebagian besar guru mengalami kesulitan dalam mengikuti kegiatan pengembangan keprofesian berkelanjutan. Hal ini disebabkan oleh berkurangnya sejumlah kegiatan yang awalnya dilaksanakan bagi para guru oleh dinas terkait dikarenakan pembatasan kegiatan masyarakat berdasarkan aturan yang berlaku. Akibatnya dari kesulitan tersebut, para guru mengalami keterbatasan informasi (lack of information), keterbatasan pengetahuan (lack of knowledge), dan keterbatasan keterampilan (lack of skills) dalam upaya meningkatkan kompetensinya. Salah satu kompetensi tersebut yaitu keterampilan dalam menulis karya ilmiah berupa penelitian literature. Keterbatasan yang berlaku tersebut dikhawatirkan berakibat pada semangat dan kesadaran para guru menjadi lemah. Jika hal tersebut terjadi, maka akan berefek pada kompetensi guru yang sulit berkembang. Dengan demikian, hal itu akan berakibat pula pada mutu pendidikan yang menurun (Arianto, et al: 2021, Nurgiansah: 2020).

Literature review adalah sebuah metode yang sistematis, eksplisit, dan reprodusibel untuk melakukan identifikasi, evaluasi, dan sintesis terhadap karya-karya hasil penelitian dan hasil pemikiran yang sudah dihasilkan oleh para peneliti dan praktisi sebelumnya (Cahyono, et al: 2019). Kajian literatur bertujuan untuk membuat analisis dan sintesis terhadap pengetahuan 
yang sudah ada terkait topik yang akan diteliti untuk menemukan ruang kosong bagi penelitian yang akan dilakukan (Hariyanti, et al: 2018).

Penelitian literature menjadi pertimbangkan topik pelatihan, yakni karena didasarkan pada penyesuain kondisi di masa pandemic covid-19. Penelitian literature bisa menjadi alternative bagi guru dalam menyiasati keterbatasan waktu dan kesempatan yang dimiliki. Penelitian literature mampu menjadi jawaban dari keresahan guru dimana walaupun para guru tidak bisa melaksanakan kegiatan di lapangan dalam memperoleh data, namun masih bisa menulis penelitian secara baik dalam bentuk penelitian literature.

Pelatihan menulis penelitian literature bagi guru di NTB yang dilaksanakan secara online merupakan solusi atas persoalan yang ada di masa pandemic covid-19. Lewat pelatihan ini guru diajak untuk berdiskusi, dibimbing, dan didampingi untuk praktik menulis tahap demi tahap. Proses pelatihan semacam ini memungkinkan bagi guru untuk memiliki pengetahuan tentang seluk-beluk penelitian literatur. Aspek yang disampaikan bukan hanya teori tetapi juga praktik. Dengan demikian pelatihan ini memberikan solusi berupa pemecahan kesulitan para guru dalam melaksanakan pengembangan dirinya (Naim: 2020, Saidah, et al: 2021).

Seorang guru yang melaksanakan pengembangan diri atau kegiatan pengembangan keprofesian berkelanjutan lainnya di samping akan dapat meningkatkan pengetahuan dan keterampilan sebagai seorang guru juga mendapat penghargaan angka kredit yang dapat diperhitungkan untuk perkembangan karirnya. Kegiatan pengembangan diri ini dilakukan selama 3 hari yaitu pada 22-24 November 2021.

Tujuan pengabdian masyarakat yang berjudul "Pelatihan Online Menulis Penelitian Literatur di Masa Pandemi Covid-19 Bagi Guru Inovatif di Provinsi Nusa Tenggara Barat" ini adalah agar para guru di NTB semakin menyadari dan memahami bahwa kondisi pandemic covid-19 bukan menjadi halangan bagi para guru dalam berkarya, namun justru menjadi momentum para guru dalam meningkatkan dan mengembangkan keterampilan dirinya secara adaptif khususnya dalam mengembangkan keterampilan menulis penelitian literatur.

\section{Solusi Permasalahan Mitra}

NTB sebagai salah satu wilayah yang mengalami pembatasan kegiatan di bidang pendidikan karena terdampak pandemic covid-19, rata-rata guru di wilayah NTB masih kesulitan dalam melaksanakan kegiatan pengembangan diri berupa penulisan karya ilmiah, terutama penulisan penelitian literature. Oleh karena itu, pelatihan online yang dilakukan diharapkan mampu mengatasi permasalahan para guru dalam meningkatkan kompetensinya di bidang pengembangan keprofesian berkelanjutan berupa menulis karya ilmiah dalam bentuk penelitian literature secara baik dan benar sesuai standar yang berlaku.

\section{METODE PENELITIAN}

Pelaksanaan kegiatan pengabdian kepada masyarakat dengan tema "Pelatihan Online Menulis Penelitian Literatur di Masa Pandemi Covid-19 Bagi Guru Inovatif di Provinsi Nusa Tenggara Barat" ini diawali dengan observasi kemudian selanjutnya dilakukan rapat kordinasi antara tim kegiatan pengabdian kepada masyarakat dengan pihak lembaga Pusat Pengembangan Pendidikan dan Pelatihan Indonesia (P4I) sebagai lembaga penyelenggara pelatihan.

Pelaksanaan kegiatan pengabdian kepada masyarakat dilakukan secara online, menggunakan flatform online meeting yakni zoom meeting yang resmi dan Whatsapp Group Online untuk diskusi di luar jam kegiatan. Kegiatan pelatihan secara tehnis dilakukan di wilayah provinsi Nusa Tenggara Barat (NTB). Kegiatan dilakukan pada tanggal 22 sampai dengan 24 November 2021 yang dihadiri oleh seluruh peserta yang terdiri dari guru dan kepala sekolah di wilayah Nusa Tenggara Barat. Kegiatan dilakukan secara paralel selama 3 hari yang terdiri dari 3 bagian kegiatan yaitu, pembuka, inti, dan penutup. 


\section{HASIL DAN PEMBAHASAN}

\section{Hasil}

Secara keseluruhan kegiatan berjalandengan baik sesuai dengan perencanaan. Semua pihak dapat bekerjasama dengan baik. Para peserta yang terdaftar seluruhnya mengikuti kegiatan pelatihan dari awal sampai akhir. Seluruh peserta diberikan materi yang terkait dengan penelitian literature berikut dengan contohnya. Para peserta merasa sangat senang dan bersemangat berdasarkan hasil angket online yang diberikan di akhir kegiatan. Hal tersebut terjadi karena peserta tidak perlu mengeluarkan biaya yang banyak dan bisa melaksanakan dan mengikuti kegiatan pelatihan dari tempat mereka masing-masing.

\section{Pembahasan}

Dalam kegiatan pengabdian kepada masyarakat ini, dilakukanlah 5 tahapan untuk mencapai tujuan yang diharapkan, yaitu:

\section{Observasi}

Kegiatan observasi dan survey adalah tahap awal untuk rencana kegiatan PKM yang sudah dirancang oleh tim, untuk selanjutnya didiskusikan dengan peserta sebagai mitra. Observasi ini menentukan apakah rencana pengabdian dapat terlaksana sesuai dengan rencana awal ataukah ada sedikit modifikasi bentuk dan tema yang akan dilaksanakan sesuai dengan kondisi real mitra yang dituju, dalam hal ini yang menjadi mitra pengabdian adalah guru seNTB yang terdaftar sebagai peserta.

Identifikasi masalah

Pelaksanaan kegiatan identifikasi masalah dilakukan dengan melakukan wawancara dan menyebarkan google form terkait pengembangan penulisan karya ilmiah yang diisi oleh para guru sebagai peserta. Beberapa peserta diwawancarai melalui video call terkait permasalahan pengembangan profesi berkelanjutan. Peserta yang diwawancarai dipilih secara acak dan berdasarkan lokasi wilayah tugas. Berdasarkan hasil identifikasi masalah yang dihadapi oleh guru maka ditemukan kendala yakni minimnya pengetahuan dan pemahaman guru mengenai penulisan karya ilmiah berupa penelitian literature. Langkah yang dilakukan oleh pihak sekolah dan guru masih sebatas memberikan anjuran dan sosialisasi terbatas dan belum sampai pada tahap memberikan kegiatan konkret mengenai penulisan penelitian literatur. Berdasarkan hasil identifikasi masalah ini, maka diketahui bahwa masalah yang dihadapi oleh sekolah dan menjadi prioritas pengabdian adalah terhadap pemahaman pentingnya pelatihan menulis penelitian literature bagi guru sebagai bagian dari pengembangan profesi berkelanjutan saat situasi pandemi. Hasil dari identifikasi masalah ini yang kemudian dilakukan tindak lanjut untuk mempersiapkan bentuk pelatihan bagi peserta.

Persiapan

Persiapan bentuk kegiatan disesuaikan dengan hasil identifikasi masalah yang dihadapi agar kegiatan yang diberikan tepat dan sesuai dengan masalah yang dihadapi. Berdasarkan hasil idenfikasi masalah tersebut di atas, maka bentuk kegiatan yang dipersiapkan, yaitu: 1) penjelasan secara teoritis tentang penelitian literatur 2) memberikan pemahaman dan pengetahuan mengenai langkah penulisan penelitian literature berupa ide, teknik pengumpulan data, teknik analisis data, sistematika laporan, dan sistematika artikel. 3) Monitoring dan evaluasi terhadap kegiatan. Dalam persiapan kegiatan ini, semua yang dibutuhkan dalam kegiatan disiapkan baik materi dan modul ceramah dan diskusi, perlengkapan yang dibutuhkan dalam kegiatan pelatihan.

\section{Pelaksanaan}

Pelaksanaan kegiatan dilakukan secara parallel dan langsung secara online melalui zoom meeting yang disiapkan. Kegiatan berlangsung selama 3 hari mulai dari tanggal 22 sampai dengan 24 November 2021. Kegiatan dilakukan mulai dari kegiatan pembukaan, kegiatan inti sampai dengan kegiatan penutup. Adapun struktur kegiatan pelatihan menulis penelitian literature yang dilaksanakan adalah sebagai berikut: 
Tabel 1. Struktur Kegiatan Pelatihan Menulis Penelitian Literature

\begin{tabular}{|c|l|c|}
\hline No & \multicolumn{1}{|c|}{ Materi } & JP \\
\hline 1 & Konsep Dasar Penelitian Literatur & $\mathbf{2}$ \\
\hline 2 & Ide Penelitian Literatur & $\mathbf{2}$ \\
3 & Teknik Pengumpulan Data Penelitian Literatur & $\mathbf{4}$ \\
4 & Teknik Analisis Data Penelitian Literatur & $\mathbf{4}$ \\
5 & Sistematika Laporan Penelitian Literatur & $\mathbf{4}$ \\
6 & Sistematika Artikel Ilmiah Penelitian Literatur & $\mathbf{4}$ \\
$\mathbf{7}$ & Diskusi dan Pembimbingan Penelitian Literatur & $\mathbf{2 0}$ \\
\hline
\end{tabular}

\section{Evaluasi}

Monitoring dan evaluasi terhadap dampak dari kegiatan tersebut, dilakukan untuk mengetahui ketercapaian kegiatan yaitu meningkatnya pemahaman dan keterampilan peserta yang terdiri dari para guru di wilayah Nusa Tenggara Barat (NTB) dalam menulis penelitian literatur. Setelah kegiatan ini dilakukan, maka selanjutnya proses monitoring dan evaluasi dilakukan untuk melihat keefektifan kegiatan ini. Dari hasil monitoring dan evaluasi ini, diperoleh data bahwa sebagai berikut: 1) Para guru sebagian besar sudah mampu mengembangkan kompetensi diri yakni para guru memahami secara teoritis mengenai penelitian literatur. 2) Para guru sebagian besar sudah terampil dalam menyusun serta mengembangkan penelitian literature.

\section{KESIMPULAN \\ Simpulan}

Berdasarkan kegiatan pengabdian kepada masyarakat yang dilakukan, maka dapat disimpulkan bahwa: 1) Para guru sebagian besar sudah mampu mengembangkan kompetensi diri yakni para guru memahami secara teoritis mengenai penelitian literatur. 2) Para guru sebagian besar sudah terampil dalam menyusun serta mengembangkan penelitian literature sebagai bagian dari pengembangan keprofesian berkelanjutan yang dibutuhkan oleh para guru dalam meningkatkan mutu pendidikan di NTB terutama di saat masa pandemi covid-19.

\section{Saran}

Adapun saran yang dapat direkomendasikan berdasarkan hasil kegiatan pelatihan ini adalah: 1) Menyadari dan memahami bahwa di masa pandemic covid-19 para guru masih bisa mengikuti kegiatan dengan pendekatan online. 2) Pelaksanaan pelatihan menulis penelitian literature bisa terus diikuti dan dilaksanakan secara terjadwal dengan disesuaikan pada kondisi yang berlaku.

\section{DAFTAR PUSTAKA}

Arianto, F., Mustaji, M., Masitoh, S., Kholidya, C. F., \& Hamsia, W. (2021). Online Project Based Learning dalam Meningkatkan Kompetensi Guru dalam Menulis Karya Ilmiah. ELSE (Elementary School Education Journal): Jurnal Pendidikan dan Pembelajaran Sekolah Dasar, 5(1), 01-10. http://dx.doi.org/10.30651/else.v5i1.7172

Cahyono, E. A., Sutomo, N., \& Hartono, A. (2019). Literatur Review; Panduan Penulisan Dan Penyusunan. Jurnal Keperawatan, 12(2), 12-12. https://orcid.org/0000-0002-8499$\underline{9194}$

Handarini, O. I., \& Wulandari, S. S. (2020). Pembelajaran daring sebagai upaya study from home (SFH) selama pandemi covid 19. Jurnal Pendidikan Administrasi Perkantoran (JPAP), 8(3), 496-503. https://journal.unesa.ac.id/index.php/jpap/article/view/8503

Hariyanti, N. T., \& Wirapraja, A. (2018). Pengaruh influencer marketing sebagai strategi pemasaran digital era moderen (Sebuah studi literatur). Eksekutif, 15(1), 133-146. https://jurnal.ibmt.ac.id/index.php/jeksekutif/article/view/172

Karim, W., Haque, A., Anis, Z., \& Ulfy, M. A. (2020). The movement control order (mco) for covid-19 crisis and its impact on tourism and hospitality sector in 
malaysia. International Tourism and Hospitality Journal, 3(2), 1-7. http://irep.iium.edu.my/83134/1/83134_The\%20movement\%20control\%20order\%20 $\% 28 \mathrm{MCO} \% 29 . \mathrm{pdf}$

Lim, C. Y., Bohn, M. K., Lippi, G., Ferrari, M., Loh, T. P., Yuen, K. Y., ... \& Horvath, A. R. (2020). Staff rostering, split team arrangement, social distancing (physical distancing) and use of personal protective equipment to minimize risk of workplace transmission during the COVID-19 pandemic: a simulation study. Clinical biochemistry, 86, 15-22. https://doi.org/10.1016/j.clinbiochem.2020.09.003

Naim, N. (2020). Pelatihan Menulis Artikel Jurnal Secara Online Bagi Mahasiswa Jurusan Ilmu Alquran dan Tafsir IAIN Tulungagung. Fajar: Media Komunikasi dan Informasi Pengabdian Kepada Masyarakat, 20(2). http://repo.uinsatu.ac.id/id/eprint/19925

Nurgiansah, T. H. (2020). Pelatihan Penulisan Artikel Ilmiah Bagi Mahasiswa PPKn Universitas PGRI Yogyakarta. Jurnal Nasional Pengabdian Masyarakat, 1(1), 16-23. https://doi.org/10.47747/pengabdiankepadamasyarakat.v1i1.114

Sadikin, I. S., Lestari, S., \& Aini, S. (2020). Pembelajaran daring interaktif, bermakna dan menarik sebagai upaya optimalisasi proses pembelajaran masa pandemi covid19. Jurnal Pengabdian Pada Masyarakat, 5(4), 897-905. https://doi.org/10.30653/002.202054.647

Saidah, Z., \& Rahmah, A. G. (2021). MENINGKATKAN KETRAMPILAN MENULIS KARYA ILMIAH DI MASA PANDEMI COVID-19 DI MTs SALAFIYAH 2 GRESIK. Jurnal Pengabdian Al-Ikhlas Universitas Islam Kalimantan Muhammad Arsyad Al Banjary, 7(1). http://dx.doi.org/10.31602/jpaiuniska.v7i1.5403

Sihotang, H., Nadeak, B., \& Siregar, R. (2020). Penerapan Belajar Mandiri dengan Strategi Efektif pada Masa Pandemi Covid-19 Bagi Remaja HKBP Duren Jaya Bekasi. JURNAL ComunitÃ Servizio: Jurnal Terkait Kegiatan Pengabdian Kepada Masyarakat, Terkhusus Bidang Teknologi, Kewirausahaan Dan Sosial Kemasyarakatan, 2(2), 393-405. https://doi.org/10.33541/cs.v2i2.1940

Windrawanto, Y. (2015). Pelatihan dalam Rangka Pengembangan Keprofesian Berkelanjutan Guru: Suatu Tinjauan Literatur. Satya Widya, 31(2), 90-101. https://doi.org/10.24246/j.sw.2015.v31.i2.p90-101 